AL IBTIDA: JURNAL PENDIDIKAN GURU MI (2017) Vol 4 (1): 17-28

DOI: http://dx.doi.org/10.24235/al.ibtida.snj.v4i1.1368

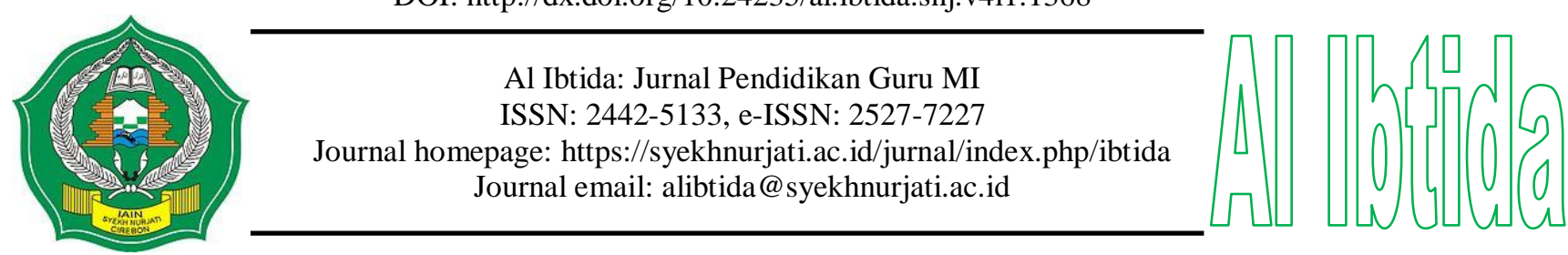

\title{
Nilai-Nilai Kemanusiaan dalam Buku 100 Cerita Anak Pilihan dan Kesesuaiannya Sebagai Bahan Pembelajaran Sastra di SD/MI
}

\author{
Agus Kichi Hermansyah* \\ *Jurusan Pendidikan Guru Sekolah Dasar, Fakultas Keguruan dan Ilmu Pendidikan, \\ Universitas Musamus Merauke \\ Email: aguskichi@gmail.com
}

Received 23 February 2017; Received in revised form 18 April 2017; Accepted 05 May 2017

Published online 20 June 2017

\begin{abstract}
Abstrak
Penelitian ini bertujuan mendeskripsikan nilai-nilai kemanusiaan yang terdapat dalam buku 100 Cerita Anak Pilihan dan kesesuaiannya sebagai bahan pembelajaran sastra di SD/MI. Metode penelitian yang digunakan dalam penelitian adalah studi kepustakaan dengan subjek penelitian buku 100 Cerita Anak Pilihan karya Ammy dan Rani. Objek penelitian ini adalah nilai-nilai kemanusiaan dan kesesuaiannya sebagai bahan pembelajaran sastra. Pendekatan yang digunakan adalah pendekatan pragmatik. Metode pengumpulan data yang digunakan adalah metode pengumpulan dokumen. Data dianalisis dengan menggunakan teknik analisis deskriptif kualitatif. Hasil penelitian ini adalah ditemukannya: (1) nilai-nilai kemanusiaan dalam buku 100 Cerita Anak Pilihan yang terdiri atas nilai moral kepribadian dan moral sosial, dan (2) buku 100 Cerita Anak Pilihan dapat digunakan sebagai bahan pembelajaran sastra di sekolah dasar/ madrasah ibtidaiyah.
\end{abstract}

Kata Kunci: cerita anak, nilai-nilai kemanusiaan, pembelajaran sastra.

\begin{abstract}
This research aimed to describe the values of humanity contained in 100 Cerita Anak Pilihan book and appropriate as literary learning materials at elementary schools. The Method of this research is literature review with subjects were 100 Cerita Anak Pilihan book created by Ammy and Rani. The object of this study is values of humanity and their appropriate as learning materials in literature. The approach used is a pragmatic approach. Data collection method used a method of collecting documents. Data were analyzed using qualitative descriptive analysis techniques. Results from this study is the discovery of: (1) the values of humanity in the 100 Cerita Anak Pilihan book consisting of personality morals values and social morals, and (2) 100 Cerita Anak Pilihan book can be used as a learning material literature in elementary schools.
\end{abstract}

Keywords: story child, values of humanity, literary learning. 


\section{PENDAHULUAN}

Sastra dan tata nilai merupakan dua komponen sosial yang saling melengkapi. Sastra sebagai produk kehidupan mengandung nilai-nilai individu (kepribadian), sosial, filsafat, religi, dan sebagainya, baik yang bertolak dari pengungkapan kembali maupun yang mempunyai penyodoran konsep baru (Suyitno, 1986: 3). Sastra tidak hanya memasuki ruang serta nilai-nilai kehidupan personal, tetapi juga nilai-nilai kehidupan manusia dalam arti yang komprehensif. Salah satu nilai yang dimaksud adalah nilai kemanusiaan.

Berbicara nilai kemanusiaan, berarti tidak terlepas dari unsur manusia itu sendiri. Dengan kata lain, nilai tersebut muncul dilatarbelakangi oleh fenomena sosial yang terjadi di masyarakat. Jadi, dapat dikatakan bahwa nilai kemanusiaan merupakan sesuatu yang lahir di tengah masyarakat karena adanya fenomen-fenomena sosial yang mampu memberikan pengaruh baik dan dampak positif bagi masyarakat.

Nilai kemanusiaan penting untuk dikaji atau dianalisis karena nilai kemanusiaan akan diarahkan untuk pembentukan pribadi manusia sebagai makhluk sosial. Adanya analisis nilai kemanusiaan dalam sebuah karya sastra akan memudahkan pembaca khususnya atau masyarakat pada umumnya memahami, dan mengenal nilai-nilai kemanusiaan yang terdapat dalam karya sastra. Dengan demikian, pembaca lebih mudah untuk mengaplikasikan nilai-nilai kemanusiaan tersebut dalam kehidupan sehari-hari.

Secara umum cerita anak yang ada, baik yang berasal dari dalam negeri maupun dari negeri lain, dapat diambil nilai-nilai atau pesan moralnya. Nilai-nilai atau pesan moral dalam sebuah karya sastra dapat berupa: (1) nilai moral kepribadian, (2) nilai moral sosial, dan (3) nilai moral religius (Suwignyo dan Harsiati dalam Rohmah, Tanpa tahun: 42 - 44). Namun dalam kajian ini, yang akan dijabarkan adalah nilai moral kepribadian dan nilai moral sosial. Melalui pengenalan nilai-nilai kemanusiaan tersebut suatu sastra dapat dimanfaatkan untuk dunia pendidikan, khususnya pembelajaran sastra di Sekolah Dasar/Madrasah Ibtidaiyah (SD/MI). Lebih lanjut, Kusmarwanti (2012) menyebutkan melalui pembelajaran sastra dapat menjadi sarana yang efektif untuk pendidikan karakter.

Sastra khususnya humaniora sangat berperan penting sebagai media dalam pentransformasi sebuah nilai termasuk halnya nilai kemanusiaan (Antilan, 2010: 28). Oleh karena itu, nilai-nilai kemanusiaan dapat dimunculkan di dalam kehidupan sehari-hari melalui karya sastra sebagai bahan atau materi pembelajarannya. Banyak sekali buku-buku yang dapat digunakan sebagai bahan atau materi pembelajaran di sekolah. Salah satu buku yang dapat digunakan untuk pentransformasian nilai-nilai kemanusian dalam pembelajaran sastra di SD/MI adalah buku 100 Cerita Anak Pilihan karya Ammy dan Rani. 
Buku 100 Cerita Anak Pilihan karya Ammy dan Rany merupakan kumpulan dongeng yang sudah beredar di seluruh dunia dan merupakan favorit anak-anak. Cerita yang disajikan kembali menjadi sangat segar dan membuat pembaca khususnya anak-anak akan semangat untuk membaca, memahami makna dan menumbuhkan sikap-sikap atau karakter positif dalam diri anak. Buku ini merupakan kumpulan dongeng singkat yang terdiri mulai dari satu hingga lima halaman untuk setiap ceritanya. Cerita-cerita dalam buku ini disajikan dengan bahasa yang sederhana oleh penyusun, sehingga tepat digunakan oleh anak-anak. Beberapa cerita pula dilengkapi dengan ilustrasi gambar yang membuat buku ini semakin menarik untuk dibaca.

Buku 100 Cerita Anak Pilihan karya Ammy dan Rani syarat akan nilai-nilai kemanusian, sekalipun cerita-cerita yang disajikan banyak diperankan oleh binatang (cerita Fabel). Pesan moral/nilai-nilai yang terdapat di dalamnya disajikan secara implisit maupun eksplisit. Secara implisit yaitu penyampaian nilai-nilai atau pesan moral itu disiratkan dalam tingkah laku tokohtokoh cerita, jalan cerita, ataupun peristiwa-peristiwa yang terjadi dalam cerita-cerita. Sedangkan eksplisit yaitu penulis/pengarang menyampaikan seruan, saran, peringatan, anjuran, larangan dan sebagainya pada tengah atau akhir cerita secara langsung (Sudjiman, 1986: 57-58). Pentingnya materi sastra disampaikan di sekolah disebutkan oleh Susanti (2015: 152) karena dalam sastra terdapat nilai-nilai kehidupan yang tidak diberikan secara perskriptif ...harus begini, jangan begitu... Nilai-nilai atau pesan moral biasanya mencerminkan pandangan hidup pengarang yang bersangkutan, dan hal itulah yang ingin disampaikannya kepada pembaca melalui sebuah karya sastra yang diciptakan.

\section{METODE PENELITIAN}

Penelitian ini merupakan penelitian kualitatif dengan jenis penelitian studi kepustakaan. Pendekatan yang digunakan dalam penelitian ini adalah pendekatan pragmatik. Ratna (2009:72) mengatakan pendekatan pragmatik memiliki manfaat terhadap fungsi-fungsi karya sastra dalam masyarakat, perkembangan dan penyebarluasannya, sehingga manfaat karya sastra dapat dirasakan. Dengan indikator pembaca dan karya sastra, tujuan pendekatan pragmatik memberikan manfaat bagi pembaca.

Penelitian ini termasuk penelitian kualitatif dengan metode pengumpulan data adalah dokumen. Penelitian ini mendeskripsikan atau menggambarkan nilai-nilai kemanusiaan apa saja yang ada dan kesesuaiannya sebagai bahan pembelajaran sastra di kelas, kemudian menganalisis dan menafsirkannya. Subjek penelitian ini adalah Buku 100 Anak Cerita Pilihan karya Ammy dan Rani. Pemilihan buku cerita tersebut sebagai subjek penelitian karena secara pribadi penulis tertarik dengan cerita-cerita dalam buku tersebut. Alasan lain yang mendasari pemilihan buku 
100 Cerita Anak Pilihan sebagai subjek penelitian karena banyaknya nilai-nilai kemanusiaan yang dapat dikenalkan kepada siswa atau pembaca secara umum. Objek penelitian dalam penelitian ini adalah nilai-nilai kemanusiaan yang terdapat dalam buku 100 Cerita Anak Pilihan karya Ammy dan Rani dan kesesuaiannya sebagai bahan pembelajaran sastra.

Setelah data dokumen terkumpul, selanjutnya data dikaji menggunakan metode analisis deskriptif kualitatif yaitu tahap pemerosesan, yakni reduksi data, penyajian data, dan kesimpulan (Sugiyono, 2013: 338 - 345). Data berupa nilai-nilai kemanusiaan buku 100 Cerita Anak Pilihan disajikan secara jelas dan alamiah tanpa adanya proses statistik. Tahap selanjutnya yang dilakukan dalam kajian ini adalah penarikan simpulan. Simpulan yang dibuat berdasarkan data yang telah disajikan yakni tentang nilai-nilai kemanusiaan buku 100 Cerita Anak Pilihan dan kesesuaiannya sebagai bahan pembelajaran sastra.

\section{HASIL PENELITIAN DAN PEMBAHASAN}

\section{Nilai-Nilai Kemanusiaan dalam Buku 100 Cerita Anak Pilihan Karya Ammy dan Rany}

Ada beberapa nilai-nilai kemanusiaan yang terdapat dalam buku 100 Cerita Anak Pilihan Karya Ammy dan Rany. Nilai-nilai kemanusiaan tersebut dapat dijadikan sebagai bahan atau materi dalam pembelajaran sastra di SD/MI. Nilai-nilai kemanusiaan tersebut terdiri dari nilai moral kepribadian dan nilai moral sosial. Berikut hasil temuan nilai-nilai kemanusiaan yang terdapat dalam buku 100 Cerita Anak Pilihan karya Ammy dan Rani.

\section{Nilai Moral Kepribadian}

Nilai moral kepribadian merupakan nilai yang berhubungan dengan nilai-nilai kepribadian seseorang. Nilai-nilai dalam moral kepribadian terdiri atas: (1) kehati-hatian, (2) kejujuran/ketidakjujuran, (3) keberanian, (4) kekritisan dan kekreatifan, (5) kerendahatian, dan (6) kebertanggungjawaban. Masing-masing penjabarannya sebagai berikut.

Pertama, kehati-hatian dalam bertindak yaitu meliputi kehatian-hatian dalam bertindak agar tidak mencelakai diri sendiri dan orang lain, kehati-hatian dalam menilai dan memutuskan sesuatu, dan kehati-hatian agar tidak terpancing oleh hal-hal yang tidak menyenangkan. Hal tersebut terbukti dari kutipan cerita berikut ini yang diambil dari cerita yang berjudul "Tersedak Tulang",

"Hai tunggu, tunggu teman. Bantu aku untuk mengeluarkan tulang dari tenggorokanku," kata Si Rubah dengan memelas. Sejenak sang Bangau menaruh rasa iba. Kemudian ia sadar. Bagaimanapun juga seekor Rubah tetaplah Rubah. Bangau berbalik hendak berlalu, tapi rasa ibanya muncul lagi. “Jangan takut, teman. Aku tak akan melukaimu. Bantulah aku," si Rubah kembali memohon. 
"Baiklah, pegang janjimu dan bukalah mulutmu," kata si Bangau. Benar saja, ketika kepalanya melongok ke dalam moncong si Rubah, ia melihat sepotong kecil tulang melintang di ujung tenggorokan si Rubah.

Dengan hati-hati si Bangau mencabut tulang itu dan bergebas menjauhinya, "Kemarilah, Bangau, Aku ingin mengucapkan terima kasih padamu," kata Rubah.

"Tidak apa-apa Rubah, ucapkan saja dari sana. Aku bisa mendengarnya," kata si Bangau tetap menjauh (Ammy \& Rani, 2014: 38-39).

Kutipan tersebut menunjukkan kehati-hatian yang dilakukan oleh si Bangau, ia mencoba untuk berhati-hati dari apa yang akan dilakukan oleh si Rubah. Si Rubah yang awalnya berhasil meminta bantuan karena ada tulang yang melintang di ujung tenggorokan dan dibantu oleh Bangau. Untuk kedua kalinya si Rubah hendak berterima kasih dan meminta Bangau untuk mendekat, tetapi kehati-hatian Bangau membuatnya selamat untuk tidak diterkam oleh Rubah. Seekor Rubah tetaplah seekor Rubah yang memiliki pemikiran untuk memangsa si Bangau sekalipun ia telah menolongnya.

Kedua, nilai kejujuran/ketidakjujuran yaitu meliputi sikap kejujuran yang akan mendatangkan keuntungan dan ketidakjujuran yang pada dasarnya akan mendatangkan kerugian/kecelakaan. Berikut ini temuan dalam kajian buku 100 Cerita Anak Pilihan.

"Tiba-tiba muncul Dewa Merkuri yang menguasai sungai tersebut. Dewa Merkuri bertanya, "Ada apa?”. "Mata kapakku tenggelam ke dasar sungai. Itulah hartaku satu-satunya yang dapat membantu bekerja mendapatkan kayu untuk dijual," jawab tukang kayu itu.

"Akan ku bantu mengambilkan." Serta merta Dewa Merkuri menyelam dan segera kembali dengan sebuah mata kapak berwarna Emas.

"Inikah mata kapakmu?" tanyanya pada tukang kayu.

"Bukan.” Sahut tukang kayu. Kembali Dewa Merkuri menyelam. Diubahnya mata kapak itu menjadi perak. Ia kembali kepada tukang kayu dan bertanya, "inikah milikmu?".

"bukan, milikku adalah mata kapak yang terbuat dari besi biasa, sudah jelek." Dewa Merkuri segera menyelam dan mengubah mata kapak itu kembali ke aslinya. Tukang kayu pun gembira melihat kapaknya kembali. Dewa Merkuri berkata, "Karena kejujuranmu, kuberikan juga kapak perak dan emas ini."

Tukang kayu sangat gembira. Dia pun menceritakan hal itu pada temantemannya. Seorang temannya yang juga tukang kayu ingin sekali memiliki kapak emas dan perak. Dia pun segera pergi ke sungai yang sama. Dengan sengaja ia lemparkan mata kapaknya ke dalam sungai. Segera ia menangis meraung-raung, berharap Dewa Merkuri datang menolong. Dewa Merkuri pun datang (Ammy \& Rani, 2014: 160-161).

Kutipan tersebut berada dalam cerita yang berjudul "Kejujuran Tukang Kayu". Seorang yang jujur diceritakan mendapatkan rejeki atas kejujurannya tidak mengakui kapak emas dan kapak perak yang ditawarkan oleh Dewa Merkuri. Karena kebaikan Dewa Merkuri, 
ia memberikan kapak emas itu kepada Tukang Kayu yang jujur. Masih pada judul yang sama seorang Tukang Kayu yang lainnya, karena hendak memiliki kapak emas dan kapak perak, ia melalukan hal yang sama dengan apa yang dilakukan Tukang Kayu yang jujur tersebut. Karena keserakahannya itu, Tukang Kayu yang tidak jujur tidak mendapatkan apa-apa, bahkan kehilangan kapak miliknya sendiri. Pernyataan tersebut ditunjukkan pada teks berikut.

"Mata kapakku terlempar ke dalam sungai. Maukah kau menolongku?” tukang kayu itu menjawab.

"Baiklah," ujar Dewa Merkuri. Ia pun menyelam dan tak lama naik lagi. "Inikah kapakmu?" tanyanya sambil mengacungkan mata kapak emas. Mata tukang kayu itu berbinar-binar, "Ya, ini milikku!” Dewa Merkuri kemudian mengeluarkan kapak perak. "Ini milikmu juga?" tanyanya. "Ya, betul," jawab tukang kayu.

"Sebentar, ini pasti milikmu juga," kata Dewa Merkuri sambil mengeluarkan kapak aslinya. "Ya, tentu, saja," tukang kayu itu kembali menjawab. "Ah, kau bukan orang jujur. Kapak emas dan kapak perak itu bukan milikmu. Akan kuhilangkan keduanya," kata Dewa Merkuri (Ammy \& Rani, 2014: 161).

Kutipan diatas menunjukkan bahwa ketidakjujuran/ kebohongan akan mengakibatkan rasa bersalah dan kehilangan kapak yang dimiliki Tukang Kayu yang tidak jujur.

Ketiga, keberanian terdiri atas sikap keberanian mengemukakan pendapat, melawan kezaliman, mempertahankan sikap yang benar dan keberanian menerima kenyataan. Nilai keberanian dalam buku cerita anak tersebut ditunjukkan pada salah satu cerita yang berjudul "Hansel dan Grethel (Brothers Grimm)" yang menceritakan seorang ibu tiri yang tidak menyukai dan menginginkan anak tirinya. Dengan penuh kebimbangan suami mengikuti permintaan istrinya untuk meninggalkan Hansel dan Grethel di hutan. Di tengah hutan, Hansel dan Grethel bertemu dengan nenek sihir yang tinggal di rumah Jahe yang terdapat banyak sekali makanan. Nenek Sihir tersebut hendak menjadikan keduanya sebagai santapan karena nenek sihir gemar memakan anak-anak. Namun, atas keberanian Hansel dan Grethel mereka berhasil membunuh Nenek Sihir dan melarikan diri. Cerita tersebut ditunjukkan pada teks berikut ini.

Beberapa hari, penyihir menunggu Hansel gemuk. Namun, ia tak sabar hingga diputskan akan dimasaknya Hansel esok hari. Disiapkannya oven untuk memanggang roti. Disuruhnya Grethel untuk menguji panas oven dengan cara masuk ke dalam oven.

Sekalian saja kupanggan Grethel, pikir nenek sihir itu. Untungnya, Grethel dapa menangkap maksud jahat itu dan ia berkata, "Bagaimana caranya?". "Ah, sini kutunjukkan!” seru nenek sihir kesal sambil masuk ke dalam oven. Tepat sesaat kemudian, Grehtel mendorong nenek itu dan mengunci oven dari luar hingga terpanggang (Ammy \& Rani, 2014: 168). 
Keempat, kekritisan dan kekreatifan yaitu sikap kekritisan dan kekreatifan mengerjakan masalah aktual, menciptakan dan mengembangkan peralatan yang bermanfaat baik bagi diri sendiri maupun orang lain. Nilai tersebut ditunjukkan oleh Ali Baba pada judul cerita "Ali Baba dan 40 Penyamun (Kisah dari Tanah Arab)". Seorang Ali Baba yang kritis dan kreatif dalam berbuat ditampilkan dalam cerita berikut ini.

Sepeninggal para perampok itu, Ali Baba pun turun dan melakukan hal yang sama. Begitu dirinya masuk ke gua, Ali Baba menemukan banyak keping uang emas dan permata. Diambilnya satu kantong, kemudian dia kembali ke rumah (Ammy \& Rani, 2014:175-176).

Sepenggal kutipan tersebut menceritakan Ali Baba yang tanpa sengaja melihat sekawanan perampok yang menyimpan hasil rampokannya di sebuah gua. Perampok tersebut menggunakan sandi untuk dapat masuk ke dalam gua. Hal itulah yang diamati dengan seksama oleh Ali Baba. Ali Baba pun dapat masuk dan mengambil sekantong uang emas dan membawanya pulang dan membagikannya kepada orang-orang miskin yang ada disekitarnya.

Kelima, kerendahatian meliputi sikap tidak membesar-besarkan kebaikan yang telah diperbuat. Nilai kerendahhatian ditunjukkan pada salah satu cerita yang berjudul "Persahabatan Sejati” yang diperankan oleh seekor Rusa Kecil dan seekor Keledai. Berikut kutipan teksnya.

"Siapa yang memberiku lobak besar ini, ya?" gumamnya heran. Karena sudah mempunyai kentang, ia teringat Rusa Kecil sahabatnya. Apakah Rusa Kecil punya makanan?, tanyanya dalam hati. Keledai bergegas berangkat menuju rumah Rusa Kecil. Tapi, Rusa Kecil tak ada di rumah. Keledai meletakkan lobak itu di depan rumahnya.

Ternyata, Rusa Kecil berada di ladang. Ia mencari makanan karena kehabisan makanan. Musim hujan masih lama, beruntung rusa Kecil menemukan tiga batang wortel yang besar-besar. Setibanya di rumah Rusa Kecil menemukan sebuah lobak yang sangat besar. (Ammy \& Rani, 2014:141)

Cerita persahabatan sejati di atas menceritakan sikap saling rendah hati yang dimiliki oleh Rusa dan Keledai, masing-masing saling memikirkan temannya. Tanpa diketahui temannya mereka menaruh makanan di rumah temannya. Mereka dengan tulus memberikan makanan dan saling berbagi tanpa ingin menunjukkan bahwa kebaikan yang dilakukan mereka berdua akan dilihat oleh yang lainnya.

Keenam, kebertanggungjawaban, yaitu tidak putus asa dalam mengerjakan atau mempelajari sesuatu, tidak cengeng dan tidak lekas meminta pertolongan dalam menghadapi suatu persoalan serta menanggung beban yang harus diembannya sendiri. Nilai yang 
mengandung kebertanggungjawaban dituangkan dalam cerita yang berjudul "Jack dan Biji Kacang Ajaib (Kisah dari Inggris)".

Dihibur oleh harpa ajaib itu, sang Ibu pun kembali sehat. Ibunya berkata, "Jack, bekerjalah kamu. Aku sakit karena khawatir raksasa itu akan turun dan mengejar kita. Lebih baik kita hidup seadanya dari hasil keringat sendiri."

Sejak itu, Jack pun bekerja dan mereka hidup bahagia ditemani harpa kecil yang senantiasa menghibur. (Ammy \& Rani, 2014:185)

Kutipan cerita jack dan biji kacang ajaib di atas menceritakan seorang anak bernama Jack dan Ibunya. Selama ini, Jack mendapatkan uang emas dari menaiki pohon raksasa yang ditanamnya yang merupakan tempat raksasa tinggal. Setiap harinya Jack menaiki pohon tersebut dan mengambil emas. Suatu ketika, karena ibunya telah sembuh dari sakitnya, ia memutuskan untuk menebang pohon, kawatir raksasa akan turun dan memangsa mereka. karena tanggung jawab Jack untuk menghidupi Ibunya, ia pun akhirnya bekerja dan hidup bahagia atas keringat yang dikeluarkannya.

\section{Nilai Moral Sosial}

Nilai moral sosial merupakan nilai-nilai yang berhubungan dengan hubungan antara seseorang dengan orang lain. Nilai-nilai dalam moral sosial terdiri dari: (1) penghormatan kepada orang lain, (2) kebekerjasamaan, (3) nilai kesolideran, (4) nilai pengakuan hak orang lain, (5) nilai kemusyawarahan, (6) nilai kedisiplinan, dan (7) nilai kasih sayang. Deskripsi penjelasannya adalah sebagai berikut.

Pertama, penghormatan kepada orang lain meliputi komponen nilai hormat kepada atasan, hormat kepada yang memiliki kelemahan, dan menghormati yang lainnya. Nilai moral sosial tersebut ditunjukkan pada cerita yang berjudul "Ular yang Bijaksana". Berikut kutipan cerita tersebut.

"Gajah, kamu harus menghargai binatang kecil. Mungkin saja dia lebih cerdas dari kamu yang nya punya tubuh besar," kata si Ular. Gajah berbalik marah pada Ular. Dia mengentak-entakkan kaki, hendak menginjak tubuh Ular yang melata di tanah.

Melihat gelagat itu, Ular langsung mematuk kaki si Gajah (Ammy \& Rani, 2014: 144).

Kutipan teks tersebut menceritakan jika dianalogikan yakni seorang harus menghormati orang lain. Boleh jadi seorang yang kita anggap lemah tetapi sebaliknya bahkan mereka jauh lebih kuat dibandingkan diri kita sendiri. Untuk itu kita harus menghormati dan menghagai semua orang tanpa membeda-bedakannya.

Kedua, kebekerjasamaan meliputi komponen bekerja sama untuk mengalahkan lawan dan bekerja sama untuk mencapai hasil yang baik. Nilai kebersamaan ditunjukkan pula oleh cerita yang berjudul "Hansel dan Grethel (Brothers Grimm)". Pada cerita tersebut, atas 
kerjasama yang baik antara adik dan kakak yang pada akhirnya dapat mengalahkan nenek sihir. Nilai kerjasama yang lainnya ditunjukkan pada cerita yang berjudul "Hiu dan Lumbalumba". Kutipan tersebut yakni sebagai berikut.

Seperti siang itu. Ikan Hiu dan Lumba-lumba asyik mencari makan di lautan yang dalam. Ikan Hiu sibuk memangsa Ikan yang ditemuinya. Sedangkan Lumba-lumba dengan santai memangsa ikan Kecil-kecil (Ammy \& Rani, 2014: 89-90).

Kutipan dan cerita tersebut menceritakan walaupun keduanya berbeda jenis. Hiu adalah ikan yang buas, sedang Lumba-lumba yang jinak. Ketika mencari makan, mereka selalu bekerja sama untuk mendapatkan makanannya. Mereka dapat hidup berdampingan dan mendapatkan makanan atas kerjasama yang mereka lakukan dalam perburuan ikan-ikan di lautan yang luas.

Ketiga, nilai kesolideran terhadap kawan meliputi komponen menolong kawan yang sakit, menghibur kawan yang susah dan menasehati kawan yang melakukan kesalahan. Nilai tersebut terdapat pada cerita yang berjudul "Landi, Landak Kesepian". Kutipannya yakni sebagai berikut.

"Hai Landi, mengapa kamu bersedih?” tanya Kuku. "Aku tidak punya teman, Kuku," kata Landi. Ia pun menceritakan apa yang membuat dirinya bersedih.

Landi ingin mempunyai teman seperti binatang lain.

"Ah, itu soal mudah, jangan bersedih. Seya bersedia mejadi temanmu, percayalah," kata Kuku. Keduanya lantas berjabat tangan.

"Saya sangat senang. Sekarang, punya sahabat," kata Landi bahagia (Ammy \& Rani, 2014: 77).

Pada kutipan teks cerita landi landak kesepian di atas menceritakan kehidupan Landi, seekor Landak yang merasa kesepian karena memiliki duri yang tajam, sehingga ia tidak disenangi oleh teman-temannya. Tetapi, seekor Kura-kura bernama Kuku tetap mau berteman dengannya. Sikap solider itulah yang dimiliki oleh Kuku si Kura-kura. Kuku pun secara bijak menasehati binatang-binatang lain untuk dapat menerima Landi sebagai teman. Pada akhir cerita tersebut, Landi menjadi penolong bagi teman-teman yang sedang berpesta. Mereka diintai oleh seekor Serigala. Dengan keberanian yang dimiliki Landi, akhirnya Serigala tersebut meninggalkan pesta, dan pesta pun dilanjutkan. Teman-teman yang lainnya pada akhirnya meminta maaf, dan mereka semua akhirnya berteman.

Keempat, nilai pengakuan hak orang lain meliputi komponen merampok akan dihukum, mengambil hak orang lain akan celaka, dan mencuri untuk tujuan baik. Nilai-nilai tersebut diceritakan pada judul cerita "Kena Getahnya" yang menceritakan Kancil yang dihukum oleh pak Tani karena telah mencuri hasil tanaman pak Tani. "Akhir Riwayat Sang Lutung", yang menceritakan Lutung yang mencoba mencelakai temannya menjadi celaka 
akibat perbuatannya karena Lutung berusaha mencelakai Ayam yang menjadi temannya. Dan, "Ali Baba dan 40 Penyamun (Kisah dari Tanah Arab)" yang menceritakan Ali Baba yang baik hati mengambil sedikit hasil curian dari perampok untuk dibagikan kepada orangorang yang miskin yang membutuhkan.

Kelima, nilai kemusyawarahan meliputi komponen nilai bermusyawarah untuk memecahkan masalah bersama, dan bermusyawarah untuk tidak saling menyalahkan. Nilai tersebut dituangkan pada salah satu cerita yang berjudul "Biar Lambat Asal Selamat". Kutipan cerita tersebut yakni sebagai berikut.

Di tengah-tengah perjalanan keduanya mulai kehausan. "Sepertinya kita belum menemukan kolam atau sunga, ya?" kata Kodok Muda. "Iya, betul. Kita sangat membutuhkan air untuk minum dan berenang-renang," kata kodok yang lebih tua.

"Ah, kita harus sabar, Sobat. Siapa tahu di depan sana ada sumber air," Kodok Tua mengingatkan. Kodok Muda mengiyakan dan setuju (Ammy \& Rani, 2014: 130).

Pada cerita biar lambat asal selamat di atas, sekumpulan Kodok yang tengah kehausan tidak menemukan sumber air. Mereka sejenak berdiskusi untuk bermusyawarah bagaimana mencari jalan keluarnya. Ketika mereka menemukan sumber air yakni sumur yang sangat dalam, mereka kembali berdiskusi.

"Hei, tunggu. Sumur ini memang banyak airnya. Kita tinggal melompat, masuk ke dalamnya. Tapi, sudahkah kamu pikirkan cara keluar dari sana?" cegah Kodok Tua. "Oooww, benar. Bagaimana cara kita keluar dari sana nanti, ya?" Kodok Muda mulai berpikir (Ammy \& Rani, 2014: 131).

Musyawarah yang mereka lakukan telah menyelamatkan mereka, karena mereka tidak jadi masuk ke dalam sumur. Jika mereka tidak berdiskusi, bisa saja mereka mendapatkan air dan dapat berenang-renang, tapi tidak tahu bagaimana cara keluar dari sumur yang dapat mengakibatkan kematian bagi mereka karena terperangkap di dalam sumur yang dalam.

Keenam, nilai kedisiplinan meliputi komponen nilai sikap tepat waktu, bersedia antri. Nilai disiplin yang berada pada cerita-cerita yang disajikan lebih kepada kedisiplinan untuk mendapatkan makanan. Seperti yang diceritakan pada salah satu cerita yang berjudul "Tak Mau Mencuri”. Cerita tersebut menceritakan seekor Laba-laba yang dengan sabar dan disiplinnya membuat perangkap jaring Laba-laba kemudian menikmati hasil tangkapannya.

Sreeet, sreeet, sreeet....

Seekor Laba-laba asyik membuat sarang di atas gudang di rumah petani. Ia berjalan dari satu sisi ke sisi lain, sambil membentangkan benang. Sehelai demi sehelai. Tak lama kemudian selesailah sarang di buatnya (Ammy \& Rani, 2014: 128). 
Ketujuh, nilai kasih sayang meliputi komponen persahabatan dengan sesama, tidak mencelakakan, dan menolong orang lain yang menderita. Nilai-nilai tersebut dapat terlihat pada cerita yang berjudul "Beruang Berkaki Lima". Kutipan cerita tersebut adalah sebagai berikut.

Suatu hari, Beruang berkaki lima bertemu dengan seekor Kelinci di bawah pohon di tengah hutan. "Aku lapar. Aku belum menemukan makanan sedikitpun," keluh seekor Kelinci. Saat itu memang sedang musim kemarau.

"Kebetulan, saya punya sedikit makanan. Ayo makanlah bersamamu”, ajaknya dengan senang hati. Lalu, Kelinci pun menginap di rumah Beruang berkaki lima.

Untuk membalas budi baik Beruang, keesokan harinya Kelinci membantu membersihkan rumah Beruang (Ammy \& Rani, 2014: 104).

Cerita beruang berkaki lima di atas menggambarkan bahwa sesama binatang mereka dapat saling menolong. Beruang yang cacat menolong Kelinci yang tengah kelaparan yang menunjukkan kasih sayang yang tulus. Beruang tidak membeda-bedakan, ia juga berbuat baik kepada siapa saja yang membutuhkan pertolongan. Bahkan binatang lainnya sering bermalam di rumah Beruang.

Dari beberapa contoh cerita yang telah disajikan di atas, terdapat nilai-nilai kemanusiaan yang dapat dikenalkan kepada siswa. Nilai-nilai kemanusiaan tersebut baik secara eksplisit maupun implisit. Setelah membaca cerita-cerita, guru dapat memberikan pengertian kepada siswa untuk mengambil pesan yang ada. Guru dapat memberikan tugas untuk menceritakan kembali cerita dan kemudian meminta mengungkapkan pesan yang terkandung di dalamnya. Guru dapat pula menjadikan cerita untuk dijadikan bahan dalam bermain peran atau drama, sehingga siswa lebih senang dan dapat menghayati nilai-nilai yang terkandung dalam cerita tersebut.

\section{SIMPULAN}

Berdasarkan pembahasan di atas, ada beberapa hal yang menjadi simpulan dalam penelitian ini. Pertama, dalam buku 100 Cerita Anak Pilihan karya Ammy dan Rani terdapat nilai-nilai kemanusiaan yang terdiri atas, nilai moral kepribadian dan nilai moral sosial. Nilai moral kepribadian terdiri atas: (1) kehati-hatian, (2) kejujuran/ketidakjujuran, (3) keberanian, (4) kekritisan dan kekreatifan, (5) kerendahatian, dan (6) kebertanggungjawaban, dan nilai moral sosial yang terdiri atas: (1) penghormatan kepada orang lain, (2) kebekerjasamaan, (3) nilai kesolideran, (4) nilai pengakuan hak orang lain, (5) nilai kemusyawarahan, (6) nilai kedisiplinan, dan (7) nilai kasih sayang. 
Kedua, berdasarkan beberapa pemaparan hasil kajian terhadap buku 100 Cerita Anak Pilihan, nilai-nilai kemanusian tersebut dapat diajarkan melalui menjadikan buku 100 Cerita Anak Pilihan menjadi materi atau bahan pembelajaran sastra di SD/MI.

\section{DAFTAR PUSTAKA}

Ammy \& Rani. 2014. 100 Cerita Anak Pilihan; Bunda Ammy dan Kak Rani. Yogyakarta: Pustaka Rama.

Kusmarwanti. 2012. Menumbuhkan Karakter Anak melalui Pembelajaran Sastra di Sekolah Dasar. Makalah disampaikan dalam seminar nasional dan temu alumni dies natalis ke-48 UNY di Ruang Sidang Rektorat UNY, pada 5 Mei 2012. (Online), (http://staffnew.uny.ac.id/upload/132310008/penelitian/makalah+semnasuny+pembelajar an+sastra+SD+dan+karakter+anak.pdf) di akses 2 Mei 2017.

Purba, A. 2010. Sastra Indonesia Kontemporer. Yogyakarta: Graha Ilmu.

Ratna, N. K. 2007. Sastra dan Cultural Studies; Representasi Fiksi dan Fakta. Yogyakarta: Pustaka Pelajar.

Rohmah, G. N. Tanpa Tahun. Pengaruh Nilai Cerita Anak dan Kesusasteraan dalam Menciptakan Pendidikan Humanis Bagi Anak Indonesia. Malang: Fakultas Humaniora dan Budaya, Universitas Islam Negeri Maulana Malik Ibrahim, Makalah (Online), (http://download.portalgaruda.org/article.php?article=115498\&val=5280), diakses 2 Februari 2017.

Suandi, I. N. 2008. Pengantar Metodologi Penelitian Bahasa. Singaraja: Universitas Pendidikan Ganesha.

Sudjiman, P. 1986. Memahami Cerita Rekaan. Jakarta: Pustaka Jaya.

Sugiyono. 2013. Metode Penelitian Pendidikan; Pendekatan Kuantitatif, Kualitatif, dan R\&D. Bandung: Alfabeta.

Susanti, R. D. 2015. Pembelajaran Apresisasi Sastra di Sekolah Dasar. Elementary. Vol. 3 No. 1 (http://journal.stainkudus.ac.id/index.php/elementary/article/download/1447/1323) di akses 1 Mei 2017.

Suyitno. 1986. Sastra, Tata Nilai, dan Eksegesis. Yogyakarta: Anindita. 